\title{
Factors Influencing the Decision to Retain or Remove the Bone Flap of Adult Patients with Traumatic Brain Injury: A Retrospective Study
}

\author{
Travmatik Beyin Hasarn Olan Yetişkin Hastalarn Kemik Flebini \\ Koruma veya Çıkarma Kararını Etkileyen Faktörler: \\ Retrospektif Bir Çalıșma
}

Xiaofeng WANG, Rongjun ZHANG, Zongchun TANG, Jianxin LIU, Shuzhen YANG, Wenyin LUO, Jun WANG, Yijun WEI, Jialong LI

Third Hospital of Chinese PLA, Department of Neurosurgery, 45 Dongfeng Road, Jin Tai District, Shaanxi Baoji, 721004, China

Corresponding Author: Rongjun ZHANG / E-mail: zhangrj1972@sina.com

\begin{abstract}
AIM: To investigate clinical factors that may influence the decision to preserve or remove the bone flap during the craniectomy surgery for patients of traumatic brain injury.

MATERIAL and METHODS: Clinical data from 2256 TBI patients were quantitatively analyzed and scored based on multiple clinical factors, including preoperative Glasgow Coma Scale (GCS) score, changes in pupil size, hematoma volume, time interval between injury and surgery, midline shift on CT scan, hematoma location and type, cortical collapse and the lateral ventricular shift deformation.

RESULTS: We identified several independent factors in the decision to preserve the bone flap: GCS score and pupil changes before the operation, cortical collapse, injury/surgery time interval and hematoma location. The results suggested that for patients with a combined score of $\geq 55$, their bone flap was generally retained. For cases with a score of 50-55, the surgical decision was based on the patient level of preconscious status, changes in pupil size and the extent of postoperative cortical collapse, and for patients with a score $<50$, the bone flap was generally removed.
\end{abstract}

CONCLUSION: Our scoring scheme is to identify factors that may be helpful when determining whether to remove or retain bone flap of TBI patients.

KEYWORDS: Traumatic brain injury, Bone flap, Surgical procedure, Decompressive craniectomy

ABBREVIATIONS: GCS, Glasgow coma scale; DC, decompressive craniectomy; TBI, traumatic brain injury; ICP, intracranial pressure; CPP, cerebral perfusion pressure; ICU, intensive care unit.

öz

AMAÇ: Travmatik beyin hasarı (TBI) olan hastalar için kraniyektomi sırasında kemik flebini koruma veya çıkarma kararını etkileyebilecek klinik faktörleri araştırmak.

YÖNTEM ve GEREÇLER: 2256 travmatik beyin hasarı hastasının klinik verileri kantitatif olarak analiz edildi ve preoperatif Glasgow Koma Ölçeği (GCS) skoru, gözbebeği büyüklüğü değişiklikleri, hematom hacmi, yaralanma ve ameliyat arasındaki zaman aralığı, BT taramasında orta hat kayması, hematom yeri ve tipi, kortikal çöküş ve lateral ventriküler kayma deformasyonu dahil olmak üzere birçok klinik faktöre göre derecelendirildi.

BULGULAR: Kemik flebini koruma kararında birçok bağımsız faktör tespit ettik: Operasyon öncesi GCS skoru ve gözbebeği değişiklikleri, kortikal çöküş, yaralanma/cerrahi zaman aralığı ve hematom yeri. Sonuçlar $\geq 55$ toplam puanı olan hastalarda, kemik flebinin genellikle muhafaza edildiğini düşündürmüştür. 50-55 puanı olan hastalarda cerrahi tedavi kararı hastanın önceki durumu, gözbebeği büyüklüğü değişiklikleri ve postoperatif kortikal çöküşün kapsamına dayalıydı, ve <50 puanı olan hastalarda kemik flebi genellikle çıkarılmıştı.

SONUÇ: Puanlama düzenimiz TBI hastalarında kemik flebini muhafaza etmeye veya çıkarmaya karar verirken yardımcı olabilecek faktörleri belirlemeye yarayabilir.

ANAHTAR SÖZCÜKLER: Travmatik beyin hasarı, Kemik flebi, Cerrahi prosedür, Dekompresif kraniyektomi 


\section{INTRODUCTION}

Decompressive craniectomy (DC) has been practiced since the early nineteenth century (8). Neurosurgeons often need to make empirical decisions on whether to remove or retain bone flap of traumatic brain injury (TBI) patients after draining patients' intracranial hematoma and cerebral contusion, as there is no established protocol for doctors to determine which procedure to perform for TBI patients $(5,6$, 32). If the patient undergoes the $D C$ procedure and the bone flap is removed, the patient has to undergo skull repair after their TBI-associated symptoms are under control $(15,29)$. As the additional skull-repairing procedures may expose the patient to additional risks, such as hydrocephalus, epilepsy and bleeding, craniotomy, which preserves the patient bone flap, certainly has clinical advantages $(26,27)$.Thus, a clear clinical guideline for neurosurgeons to follow when making decisions based on preoperative patient conditions remains a critical unmet need to optimize TBI patient outcome.

In an effort to establish such a standard, we retrospectively analyzed the clinical data of $2256 \mathrm{TBI}$ cases that underwent surgery in our hospital between March 2001 and March 2012. Preoperative and intraoperative patient information, as well as imaging data, were employed for statistical analysis, with the aim of isolating individual patient-derived factors correlated with the surgical decision to either retain or remove the bone flap.

\section{MATERIAL and METHODS}

\section{Patient Selection}

Upon the approval of this clinical study by the institutional ethics committee, the clinical data of 2256 adult patients (1693 males and 563 females, with ages ranging from 18 to 65) were retrospectively examined. In this study, 1765 of the cases were caused by traffic accidents, 354 cases occurred when individual fell from high ground, 97 cases were caused by direct impact and the remaining 40 cases had miscellaneous causes.

In our study 1125 cases underwent DC, with the intracranial hematoma drained and their bone flaps removed. The remaining 1131 cases underwent craniotomy with their intracranial hematoma drained and their bone flaps retained.

In the patient group with the bone flap removed (the DC group), the patient age ranged from 18 to 65 years old (43.25 \pm 6.58 ), 133 patients had a GCS score $\geq 9,890$ patients had GCS scores of 6-8, and 102 patients had GCS scores between 3 and 5 . In the patient group with the bone flap retained (the CR group), the patient age ranged from 18 to 65 years old (41.72 \pm 7.23$), 673$ patients had a GCS score $\geq 9,445$ cases had GCS scores of 6-8, and 13 patients had GCS scores of 3-5. These two patient groups showed no statistically significant difference in terms of their age distribution $(P>0.05$, unpaired student $\mathrm{t}$-test), but there is statistically significant difference with regards to GCS score ( $\mathrm{P}<0.05$, unpaired student's t-test).

\section{Methods}

All patients were scored quantitatively in the following 9 categories of clinical conditions: Preoperative GCS score, changes in pupil size; hematoma volume, time interval between injury and surgery, midline shift on CT scan, cortical collapse, hematoma location, hematomas type, and lateral ventricular shift deformation (Table I).

The design of our scoring scheme was in line with the preoperative GCS scoring system (typically a 15-point scale). Depending on changes in pupil size before the operation, patients were given a grade of 10,5 or 0 points. The hematoma volume was graded on a 10-point scale. With regards to injury/surgery time interval, previous studies have shown that the longer the time interval between injury and surgery, the greater the swelling and intracranial pressure $(16,32)$; thus, a 10-point scale was set that ranged from 1 to 8 hours, with a longer time interval leading to a lower score, as this lowered the likelihood of preserving bone flap (undergoing the CR procedure instead of DC) (12). For the injury/surgery time interval category, we also took into consideration the uneven time distribution when designing the scale to make it more reasonable. Midline shift on CT scan and lateral ventricular shift deformation had a negative correlation with the assigned score, with a greater shift resulting in a lower score.

Patient imaging data and pre/intraoperative conditions are listed in Table I. Based on the severity of the conditions, we scored each patient in order to make a statistical comparison of the patient groups. We determined the mean score \pm standard deviation $(x \pm s)$ of each patient and the mean \pm standard deviation $(x \pm s)$ of the total score, both of which were employed for statistical analysis.

Statistical analysis was performed using a commercially available program (SPSS version 15.0; SPSS, Inc).

Comparisons between the two sets of patients were made with regards to the following nine clinical factors: preoperative GCS score, changes in pupil size, hematoma volume, time interval between injury and surgery, midline shift on CT scan, cortical collapse, hematoma location, hematoma type, and lateral ventricular shift deformation.

Single factor analysis was performed and t-tests were carried out. A difference with a $P$ value $<0.05$ was considered to be statistically significant. The independent variables showing significant differences underwent multi-factor logistic regression analysis for confirmation.

\section{RESULTS}

By scoring each clinical factor using the scoring scheme described in Table I, we present in Table II the statistics for the 9 clinical factors for each of two patient groups. We found that preoperative Glasgow Coma Scale (GCS) score, changes in pupil size, hematoma volume, time interval between injury and surgery, midline shift on CT scan, hematoma location and type, cortical collapse and the Lateral ventricular shift 
deformation showed a significant association $(P<0.05)$ with the decision to perform CR (preserve the bone flap) (Table II).

We then carried out step-wise logistic regression analysis and we identified several clinical condition categories as independent factors in the decision to preserve the bone flap: GCS score before surgery, changes in pupil size before the operation, cortical collapse, injury/surgery time interval and hematoma location (Table III).
To further establish a number-based scoring system using the key clinical factors identified in Table III, we summed the scores in these categories (listed in Table IV). In the absence of postoperative bleeding and other secondary bleeding, our results suggested that a combined score of $\geq 55$ led to the preservation of the bone flap. For scores within the range of 50-55, the decision is not apparent, and ultimately the choice of operation should be decided by the patient preconscious

Table I: Clinical Factors and Scoring Scheme

\begin{tabular}{|c|c|c|c|c|c|c|c|c|c|c|}
\hline \multirow{2}{*}{$\begin{array}{l}\text { Preoperative } \\
\text { GCS Score } \\
15 \text { points }\end{array}$} & \multicolumn{3}{|c|}{ Changes in Pupil Size } & \multicolumn{2}{|c|}{ Hematoma Volume } & \multicolumn{3}{|c|}{$\begin{array}{l}\text { Injury/Surgery Time } \\
\text { Interval }\end{array}$} & \multicolumn{2}{|c|}{$\begin{array}{l}\text { Midline } \\
\text { Shift on CT Scan }\end{array}$} \\
\hline & $\mathrm{No}$ & ange & 10 points & $<30 \mathrm{ml}$ & 10 points & $60 \mathrm{~min}$ & $10 p$ & ints & None & 10 points \\
\hline 14 points & \multicolumn{2}{|c|}{$\begin{array}{l}\text { Single side of the } \\
\text { pupil dilated }\end{array}$} & 5 points & $30 \mathrm{ml}$ & 9 points & $90 \mathrm{~min}$ & \multicolumn{2}{|c|}{9 points } & $2 \mathrm{~mm}$ & 9 points \\
\hline 13 points & \multicolumn{2}{|c|}{$\begin{array}{l}\text { Both sides of the } \\
\text { pupil dilated }\end{array}$} & 0 points & $40 \mathrm{ml}$ & 8 points & $120 \mathrm{~min}$ & \multicolumn{2}{|c|}{8 points } & $4 \mathrm{~mm}$ & 8 points \\
\hline 12 points & & & & $50 \mathrm{ml}$ & 7 points & $150 \mathrm{~min}$ & \multicolumn{2}{|c|}{7 points } & $6 \mathrm{~mm}$ & 7 points \\
\hline 11 points & & & & $60 \mathrm{ml}$ & 6 points & $180 \min$ & \multicolumn{2}{|c|}{6 points } & $8 \mathrm{~mm}$ & 6 points \\
\hline 10 points & & & & $70 \mathrm{ml}$ & 5 points & $240 \mathrm{~min}$ & \multicolumn{2}{|c|}{5 points } & $10 \mathrm{~mm}$ & 5 points \\
\hline 9 points & & & & $80 \mathrm{ml}$ & 4 points & 300 min & \multicolumn{2}{|c|}{4 points } & $12 \mathrm{~mm}$ & 4 points \\
\hline 8 points & & & & $90 \mathrm{ml}$ & 3 points & $360 \min$ & $3 p$ & ints & $14 \mathrm{~mm}$ & 3 points \\
\hline 7 points & & & & $100 \mathrm{ml}$ & 2 points & $420 \min$ & & ints & $16 \mathrm{~mm}$ & 2 points \\
\hline 6 points & & & & $>100 \mathrm{ml}$ & 1 points & $480 \mathrm{~min}$ & $1 p$ & ints & $18 \mathrm{~mm}$ & 1 points \\
\hline 3-5 points & & & & & & & & & $20 \mathrm{~mm}$ & 0 points \\
\hline Cortical Collap & & Hematoma Lo & ocation & Hema & oma Type & & & $\begin{array}{l}\text { Lateral } \\
\text { Deforn }\end{array}$ & $\begin{array}{l}\text { Ventricu } \\
\text { ration }\end{array}$ & ar Shift \\
\hline $20 \mathrm{~mm}$ & & Parietal lobe & 10 points & Epidur & & 10 po & & None & 10 po & nts \\
\hline $15 \mathrm{~mm}$ & & Frontal & 8 points & Brain & & 8 po & & $2 \mathrm{~mm}$ & $8 \mathrm{po}$ & nts \\
\hline $10 \mathrm{~mm}$ & & Occipital lobe & 6 points & Subdu & & $6 \mathrm{po}$ & hts & $4 \mathrm{~mm}$ & $6 \mathrm{po}$ & nts \\
\hline $5 \mathrm{~mm}$ & & Temporal lobe & 4 points & Breaki & $g$ into ventricle & 4 po & & $6 \mathrm{~mm}$ & 4 po & nts \\
\hline $0 \mathrm{~mm}$ & & Multiple & 2 points & Multip & & 2 po & nts & $>8 \mathrm{~mm}$ & $2 \mathrm{po}$ & nts \\
\hline$>0 \mathrm{~mm}$ & & & & & & & & $>10 \mathrm{mr}$ & 0 po & \\
\hline
\end{tabular}

Table II: Statistical Analysis of Patient Groups with Bone Flap Removed or Retained

\begin{tabular}{|c|c|c|c|}
\hline Clinical Factors & Removed & Retained & P value \\
\hline 1. Preoperative GCS score & $6.2 \pm 0.4$ & $9.3 \pm 0.3$ & 0.000 \\
\hline 2. Changes in pupil size & $6.5 \pm 0.2$ & $9.6 \pm 0.3$ & 0.000 \\
\hline 3. Hematoma volume & $6.3 \pm 0.3$ & $7.4 \pm 0.4$ & 0.000 \\
\hline 4. Injury/surgery time interval & $5.7 \pm 0.3$ & $3.1 \pm 0.3$ & 0.000 \\
\hline 5. Midline shifts on CT scan & $3.5 \pm 0.4$ & $6.4 \pm 0.3$ & 0.000 \\
\hline 6. Cortical collapse & $2.8 \pm 0.4$ & $5.5 \pm 0.3$ & 0.000 \\
\hline 7. Location of hematoma & $4.0 \pm 0.4$ & $5.6 \pm 0.3$ & 0.000 \\
\hline 8. Type of hematoma & $6.5 \pm 0.3$ & $7.1 \pm 0.6$ & 0.000 \\
\hline 9. Lateral ventricular shift deformation & $8.4 \pm 0.5$ & $6.4 \pm 0.3$ & 0.000 \\
\hline Total Score & $41.5 \pm 0.4$ & $57.2 \pm 0.4$ & \\
\hline
\end{tabular}


Table III: Logistic Regression Analysis of Factors in Association with Preserving the Bone Flap

\begin{tabular}{|l|c|c|c|}
\hline Clinical Factors & Regression Coefficient & OR (95\% CI) & P value \\
\hline Preoperative GCS score & 4.186 & $1.356 \sim 34.683$ & 0.035 \\
\hline Changes in pupil size & 1.786 & $1.326 \sim 17.685$ & 0.045 \\
\hline Injury/surgery time interval & 3.675 & $1.568 \sim 33.795$ & 0.038 \\
\hline Cortical Collapse & 3.214 & $1.137 \sim 26.453$ & 0.043 \\
\hline Hematoma location & 1.342 & $1.867 \sim 24.956$ & 0.047
\end{tabular}

Table IV: Comparison of the Combined Scores of the Bone Flap Removal and Retained Patient Groups

\begin{tabular}{|l|r|r|r|}
\hline Combined Scores & Bone Flap Removed & Bone Flap Retained & Total \\
\hline$\geq 55$ & 31 & 801 & 832 \\
\hline $50-55$ & 168 & 207 & 375 \\
\hline$<50$ & 926 & 123 & 1049 \\
\hline Total & 1125 & 1131 & 2256 \\
\hline
\end{tabular}

status and the extent of cortical collapse. For patients with a score $<50$, the bone flap was generally removed.

\section{DISCUSSION}

The choice of surgical treatment for traumatic head injuries depends on the preoperative condition of the patient $(11,13$, 23). Recently, a number of surgical biomarkers for TBI patients have been proposed, and these are mainly based on ICP, CPP and imaging data $(3,7,19,30)$. Given these biomarkers, we still lack a clear set of standards for neurosurgeons to use as guidelines when deciding what type of surgery to perform: craniotomy, which ultimately preserves the bone flap, or decompressive craniectomy, which removes the bone flap $(10,14)$. Depending on the patient's condition, the hematoma or damaged brain tissue will be removed. The decision of whether to keep or remove the bone flap is collectively affected by the surgical process and prognosis in order to achieve optimal overall patient outcome (17). Decompressive craniectomy is the surgical procedure of removing the bone flap, which has been shown to reduce secondary brain edema and intracranial pressure $(7,10,13)$. However, decompression craniectomy may lead to various complications and sideeffects, including skull defects, hydrocephalus, cerebrospinal fluid leak, subdural effusion, postoperative hematoma epilepsy and other delayed complications $(15,26,27)$.

In this study, we intended to retrospectively examine patient data and use statistical analysis to derive clinical relevant factors strongly associated with the clinical decision to either preserve or remove the bone flap of patients with TBI. To quantitatively evaluate the significance of 9 independent factors, we attempted to identify a positive correlation of each patient condition with the surgical decision to preserve the bone flap by examining the contribution of each individual factor. After examining the data from 2256 cases, we were able to identify 5 key factors: operation preconscious status (GCS), the occurrence of pupil changes before the operation, cortical collapse, injury/surgery time interval and hematoma location. Patient GCS score was found to be significantly correlated with the severity of brain injury and the degree of brain edema (3). The severity of brain tissue collapse may affect the intracranial pressure. The edema usually appears 3-4 hours following injury and then gradually deteriorates, affecting intracranial pressure (2). The injury/surgery interval time is correlated with the occurrence of delayed hematomas (13). Intracranial hemorrhage and midline shift are also indications of increased intracranial pressure. When coupled with vascular compression and secondary cerebral infarction, severe brain edema may occur, which may lead to a significant increase in intracranial pressure $(8,25,31)$. A less severe injury may lead to small-scale single-focal intracranial hematoma associated with less severe postoperative cerebral edema, whereas more traumatic injury often results in multi-focal complex hematoma, which is associated with more severe cerebral edema and increased intracranial pressure (4). Based on these rationales, we included these factors into our scoring system. For factors that are partially correlated, such as the hematoma volume and midline deviation, both of which determine injury severity, their individual GCS scores are assigned lower to reflect their partially redundant contribution to the overall injury severity. Due to cerebral hypoplasia in children and the elderly brain atrophy, our study did not select these patients. In general, for patients with epidural hematoma but no preoperative herniation, the surgeon will retain the bone flap. For patients with a single intracerebral hematoma, and with no obvious cerebral contusion, the surgeon may also retain the bone flap (1). For older individuals with cerebral atrophy and a large intracranial compensatory space, surgeons usually favor the option of preserving the bone flap (22). For patients with diffuse brain swelling, extensive brain injury or incipient herniation, the decision was often to remove the bone flap (21). Other preoperative factors may also have an association with the decision regarding the bone flap (9), such as blood pressure and body temperature; however they were not 
directly correlated with the setting of treatment goals, so they were not included in this study.

The factors identified in this study, as well as the clinical scoring system described here, may be useful to the decisionmaking process regarding bone flap retention. Our study uses a single-center patient sample; therefore, the conclusions here need to be further verified by a multi-center study. Our scoring system depicted in Table IV, although not used as a standard in the clinics, was able to effectively describe the general trend as to whether the bone flap was retained or removed based on multiple patient factors. Therefore, it may aid the clinical decision-making process regarding the status of the bone flap in patients with traumatic brain injury. In order to further refine this scoring system into a clinically applicable protocol, a multi-center study is needed to ensure the reproducibility and accuracy of this protocol. With more extensive analysis, we hope to establish a clear numberbased intraoperative decision-making protocol to reduce the unnecessary mortality and morbidity associated with TBI operations and optimize patient outcome $(20,24,28)$.

\section{ACKNOWLEDGMENTS}

We thank Dr. Bobo Chen and Dr. Kunhu Zhang for assistance with the experiments, and are grateful for the financial support provided by the medical and health research project of Lanzhou Military Region (CLZ12JA19).

\section{REFERENCES}

1. Aarabi B, Simard JM: Traumatic brain injury. Curr Opin Crit Care 15:548-553, 2009

2. Akyuz M, Ucar T, Acikbas C, Kazan S, Yilmaz M, Tuncer R: Effect of early bilateral decompressive craniectomy on outcome for severe traumatic brain injury. Turk Neurosurg 20:382-389, 2010

3. Bao YH, Liang YM, Gao GY, Pan YH, Luo QZ, Jiang JY: Bilateral decompressive craniectomy for patients with malignant diffuse brain swelling after severe traumatic brain injury: $A$ 37-case study. J Neurotrauma 27:341-347, 2010

4. Chattopadhyay S, Tripathi C: Skull fracture and haemorrhage pattern among fatal and nonfatal head injury assault victims - a critical analysis. J Inj Violence Res 2:99-103, 2010

5. Cooper DJ, Rosenfeld JV, Murray L, Arabi YM, Davies AR, D'Urso P, Kossmann T, Ponsford J, Seppelt I, Reilly P, Wolfe R: Decompressive craniectomy in diffuse traumatic brain injury. N Engl J Med 364:1493-1502, 2011

6. Cooper DJ, Rosenfeld JV, Murray L, Wolfe R, Ponsford J, Davies A, D'Urso P, Pellegrino V, Malham G, Kossmann T: Early decompressive craniectomy for patients with severe traumatic brain injury and refractory intracranial hypertension--a pilot randomized trial. J Crit Care 23:387-393, 2008

7. Eberle BM, Schnüriger B, Inaba K, Gruen JP, Demetriades D, Belzberg H: Decompressive craniectomy: Surgical control of traumatic intracranial hypertension may improve outcome. Injury 41:894-898, 2010
8. Elwatidy S: Bifrontal decompressive craniectomy is a lifesaving procedure for patients with nontraumatic refractory brain edema. Br J Neurosurg 23:56-62, 2009

9. Ho CL, Wang CM, Lee KK, Ng I, Ang BT: Cerebral oxygenation, vascular reactivity, and neurochemistry following decompressive craniectomy for severe traumatic brain injury. J Neurosurg 108:943-949, 2008

10. Honeybul S, O'Hanlon S, Ho KM: Decompressive craniectomy for severe head injury: Does an outcome prediction model influence clinical decision-making? J Neurotrauma 28:13-19, 2011

11. Howard JL, Cipolle MD, Anderson M, Sabella V, Shollenberger D, Li PM, Pasquale MD: Outcome after decompressive craniectomy for the treatment of severe traumatic brain injury. J Trauma 65(2):380-385, 2008

12. Huang AP, Tu YK, Tsai YH, Chen YS, Hong WC, Yang CC, Kuo LT, Su IC, Huang SH, Huang SJ: Decompressive craniectomy as the primary surgical intervention for hemorrhagic contusion. J Neurotrauma 25:1347-1354, 2008

13. Hutchinson P, Timofeev I, Kirkpatrick P: Surgery for brain edema. Neurosurg Focus 22:E14, 2007

14. Intiso D, Lombardi $T$, Grimaldi $G$, larossi $A$, Tolfa $M$, Russo M, Di Rienzo F: Long-term outcome and health status in decompressive craniectomized patients with intractable intracranial pressure after severe brain injury. Brain Inj 25: 379-386, 2011

15. Kilincer C, Hamamcioglu MK: Surgical complications of decompressive craniectomy for head trauma. Acta Neurochir (Wien) 152:557-558, 2010

16. Lemcke J, Ahmadi S, Meier U: Outcome of patients with severe head injury after decompressive craniectomy. Acta Neurochir Suppl 106: 231-233, 2010

17. Malmivaara K, Kivisaari R, Hernesniemi J, Siironen J: Costeffectiveness of decompressive craniectomy in traumatic brain injuries. Eur J Neurol 18:656-662, 2011

18. Marinkovic I, Strbian D, Pedrono E, Vekovischeva OY, Shekhar S, Durukan A, Korpi ER, Abo-Ramadan U, Tatlisumak T: Decompressive craniectomy for intracerebral hemorrhage. Neurosurgery 65:780-786, 2009

19. McMillan TM, Teasdale GM: Death rate is increased for at least 7 years head injury: A prospective study. Brain 130: 2520-2527, 2007

20. Morgalla $\mathrm{MH}$, Will BE, Roser F, Tatagiba M: Do long-term results justify decompressive craniectomy after severe traumatic brain injury. J Neurosurg 109:685-690, 2008

21. Otani N, Takasato Y, Masaoka H, Hayakawa T, Yoshino Y, Yatsushige $H$, Miyawaki $H$, Sumiyoshi K, Sugawara T, Chikashi A, Takeuchi S, Suzuki G: Surgical outcome following a decompressive craniectomy for acute epidural hematoma patients presenting with associated massive brain swelling. Acta Neurochir Suppl 106: 261-264, 2010

22. Pompueci A, De Bonis P, Pettorini B, Petrella G, Di Chirico A, Anile C: Decompressive craniectomy for traumatic brain injury: Patient age and outcome. J Neurotrauma 24: $1182-1188,2007$ 
23. Qiu B, Xu S, Fang L, Chotai S, Li W, Qi S: Surgical strategies for neurological function preservation in severe brain contusion. Turk Neurosurg 22:329-335, 2012

24. Rosenfeld JV, Cooper J: What is the role for decompressive craniectomy in severe traumatic brain injury? Re: Decompressive craniectomy: Surgical control of intracranial hypertension may improve outcome. Injury 41:899-900, 2010

25. Rosenfeld JV, Maas Al, Bragge P, Morganti-Kossmann MC, Manley GT, Gruen RL: Early management of severe traumatic brain injury. Lancet 380:1088-1098, 2012

26. Santana-Cabrera L, Pérez-Acosta G, Rodríguez-Escot C, Lorenzo-Torrent $R$, Sánchez-Palacios $M$ : Complications of post-injury decompressive craniectomy. Int J Crit IIIn Inj Sci 2:186-188, 2012

27. Stiver SI: Complications of decompressive craniectomy for traumatic brain injury. Neurosurg Focus 26(6):E7, 2009

28. Soustiel JF, Sviri GE, Mahamid E, Shik V, Abeshaus S, Zaaroor M: Cerebral blood flow and metabolism following decompressive craniectomy for control of increased intracranial pressure. Neurosurgery 67:65-72, 2010
29. Tagliaferri F, Zani G, laccarino C, Ferro S, Ridolfi L, Basaglia $\mathrm{N}$, Hutchinson P, Servadei F: Decompressive craniectomies, facts and fiction: A retrospective analysis of 526 cases. Acta Neurochir (Wien) 154:919-926, 2012

30. Valadka $A B$, Robertson CS: Surgery of cerebral trauma and associated critical care. Neurosurgery 61: 203-221, 2007

31. Weiner GM, Lacey MR, Mackenzie L, Shah DP, Frangos SG, Grady MS, Kofke A, Levine J, Schuster J, Le Roux PD: Decompressive craniectomy for elevated intracranial pressure and its effect on the cumulative ischemic burden and therapeutic intensity levels after severe traumatic brain injury. Neurosurgery 66:1111-1119, 2010

32. Williams RF, Magnotti LJ, Croce MA, Hargraves BB, Fischer PE, Schroeppel TJ, Zarzaur BL, Muhlbauer M, Timmons SD, Fabian TC: Impact of decompressive craniectomy on functional outcome after severe traumatic brain injury. J Trauma 66:1570-1576, 2009 